Copyright (C) 2021 by Academic Publishing House Researcher s.r.o.

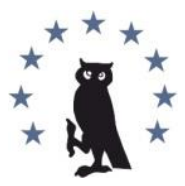

Published in the Slovak Republic

Media Education (Mediaobrazovanie)

Has been issued since 2005

ISSN 1994-4160

E-ISSN 2729-8132

2021. $17(3): 524-528$

DOI: $10.13187 / \mathrm{me} .2021 .3 .524$

www.ejournal53.com

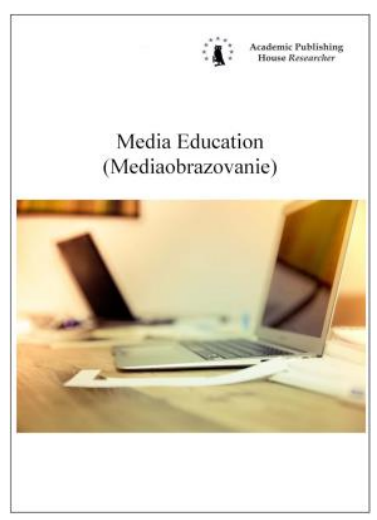

\title{
Nu, pogodi! and Tom and Jerry as the Images of Different and Departing Dultures
}

Roman Salny a, *, Victoria Voychenko a

a Rostov State University of Economics, Russian Federation

\begin{abstract}
The material of the investigation is introduced by two animated series: Tom and Jerry, created in the USA and Nu, pogodi! (Just you wait!), created in the USSR. The comparative analysis, based on their art spaces collation and the main characters' behavior models interaction, reflecting the differences between Russian and American cultures, is suggested.

During the latest decades in Russia and the USA significant cultural changes have taken place. The historic period and sociocultural relations, reflected in the animated series $\mathrm{Nu}$, pogodi! and Tom and Jerry, are left in the past forever. The audience and the experience of its images and plots perception have changed. Today Tom and Jerry might be accused of racism; the Soviet $\mathrm{Nu}$, pogodi! can be impeached for sexual (and even homosexual) motives in relations between the Wolf and the Hare. Obviously, these accusations can work with the modern sociocultural context. However, both the American and the Russian animated cartoons reflect the two cultures with a great number of differences and peculiarities, often left unnoticed by contemporary animation investigators.

As a result of the investigation conducted, it is concluded that the anthropomorphic animal worlds $\mathrm{Nu}$, pogodi! and Tom and Jerry represent two different cultures. In $\mathrm{Nu}$, pogodi! the utopian idyll of the Soviet folkloric characters is depicted, which is based on the deep-rooted Russian values such as absence of violence, self-sacrifice, fellowship, forgiveness. In Tom and Jerry the egoistic world of American characters is created, built upon the culture of self affirmation, individual success and prosperity.
\end{abstract}

Keywords: Nu, pogodi!, Tom and Jerry, animated cartoon, the USSR, the USA, culture.

\section{Introduction}

The animated cartoon Tom and Jerry was shown on the American screen in February, 1940. The company Metro-Goldwyn-Mayer thanks to its incredible success among the wide audience was able not only to respond decently to Disney's Mickey Mouse, but also overcome the financial crisis being on the edge of bankruptcy.

The Little Mouse Jerry, created by William Hanna and Joseph Barber looked more realistic than his predecessor, Mickey Mouse that seemed more helpless than his "younger brother". Moreover, Mickey Mouse didn't have such aggressive mimics and motivation as Jerry had. The author's desire to make him more brutal is seen in the first Tom and Jerry part title ("The cat gets a punch").

\footnotetext{
* Corresponding author

E-mail addresses: roman_tag82@mail.ru (R. Salny)
} 
During the first years of its existence the Cat and the Mouse have changed a lot - "if in the first parts they looked more like animals, walked on four feet, then after 1945 they gained some human resemblance, friends and relatives" (Ostapenko, 2019).

Throughout the 80-year-old Tom and Jerry history more than 160 short episodes were made, and since 1992 more than 10 full-length films have been shown on screen.

The history of the Soviet animation characters (The Wolf and the Hare) relations is much more discreet than that of the brave Mouse and the cheerful Cat. After the release of $\mathrm{Nu}$, pogodi! it was being handled that the animated cartoon was a kind of state demand, "the answer to the West", but these accusations of plagiarism are unfounded. Firstly, Tom and Jerry was shown on the Soviet screen in the early $70-\mathrm{s}$, whereas the first part of $\mathrm{Nu}$, pogodi! was available to the Soviet viewer in 1969. Secondly, on the basis of the Soviet cartoon there was a familiar, close to the Russian folklore pair the Wolf and the Hare. "But Kurlyandsiy and Hyte's Wolf was not a severe wild animal, but a lazy-bone and a simpleton being constantly wound round the smart Hare's little finger" (Ostapenko, 2019). By the way, the Hair didn't show aggression towards the Woolf but easily forgave him every time. "As the artist Kotenochkin puts it, it took him no time to draw the Hare - a cute, neat little hare with jolly eyes and fluffy ears. But despite the cuteness, the Hare is not that simple: he is tricky, witty and much smarter than the loser Wolf" (Ostapenko, 2019).

\section{Materials and methods}

The material of the investigation is represented by two animated series: Tom and Jerry, created in the USA and Nu, pogodi! (Just you wait!), created in the USSR. The comparative analysis, based on their art spaces collation and the main characters' behavior models interaction, reflecting the differences between Russian and American cultures, is conducted.

\section{Discussion}

More than 80 years have passed since the first part of Tom and Jerry release. During this period the animated series greatly affected American cultural behavior, thinking, values stereotypes spread in different countries of the world (Darling-Wolf, 2015), but, however the audience have changed and the experience of its images and plots interpretation.

During the latest decades in Russia and in the USA great cultural changes have happened. The historic period and sociocultural relations, reflected in the animated series $\mathrm{Nu}$, pogodi! and Tom and Jerry, are left in the past forever. Russian and American film animators' attempts to display the characters to the wide audience again in 2000 s failed. "The full length animated cartoon about Tom and Jerry, where they help an orphan girl to find a family, flopped... Meanwhile, the modern adaptation of $N u$, pogodi! wasn't a success either. The characters have lost their affection, turning into another advertising product" (Ostapenko, 2019).

Nowadays Tom and Jerry can be accused of racism. For instance, it's noted that in some episodes after explosions characters' faces turn black, their lips thicken, and African plaits appear and the hostess Mommy two slippers has an Afro-American accent. She was also viewed as a "black woman", serving men's society (Aravind, 2011). Due to political correctness some so called "racist scenes" have been cut from some series of Tom and Jerry.

Contemporary journalists, editors, bloggers (Davyidov, Moroz, 2019; Elizarov, 2018; Kropotkin, 2021 and others) point out some sexual (and even homosexual (!)) motives in relations between the Wolf and the Hare. Responding to them it's worth formulating some ideas about the legendary cartoon authors' creative work.

A character's image is brought to an animation artist by creative intuition and the feeling of the time he lives in. Trusting their intuition Soviet animation artists created a great number of simple, nice and cute characters, adored by millions of young viewers. In comparison with the contemporary animation characters we can't help calling them the ideal ones. Reduction of the ideal to some qualities leads to its disappearance. This is happening to the characters of the Wolf and the Hare in some contemporary journalists', bloggers' and so on critical reviews.

The historic time, the Wolf and the Hare were created in, has its peculiarities. The Wolf and the Hare are the characters of the late Soviet epoch, the time signing the shortage of consumer items; sacral following the prescribed scales of social life; cultural leisure time spending by Soviet citizens; blackmarketeers, selling hard-to-find and import goods; the youths' Western culture mimicry. There are no grounds for sexual and homosexual ambitions in the Soviet sociocultural area of the end of 1969-s - the first part of 1980-s. 
It should be admitted that Soviet animation artists mustn't be suspected of sexual energies sublimation.

The comparison of the characters of Nu, pogodi! and Tom and Jerry makes it obvious that the Soviet Wolf and Hare are much kinder than American Cat and Mouse. In the Russian animated series nobody uses rockets, dynamite, arrows to cripple some of the characters, nobody thinks of tricky traps to injure anybody.

Together with the "Oskars" and the audience's love animated series Tom and Jerry have been criticized "for these animation artists can't see the limits and bring to screen the apology of violence and cruelty for children to see" (Aleshicheva, 2021). The Cat and Mouse's charm has been saving the animated cartoon from censorship for many decades, but in 2006 the restrictions were brought in but not due to the cruelty. "British television editors began to cut the scenes of smoking and alcohol drinking" (Ostapenko, 2019).

Although the violence in the American animated series is shown in a humorous way, it's cruelly accented. That couldn't have been left the specialists' attention. Thus, according to the investigation, conducted in Pakistan, it's concluded that $82,6 \%$ of the scholars asked like the battle scenes between Tom and Jerry, 57,8 \% admitted that they have fights at school after watching them (Hassan; Daniyal, 2013: 10).

A group of Russian psychologists (Anikeeva et al., 2019) conducted the investigation of elementary school children's perception of Russian native and Western animated cartoons, particularly Tom and Jerry and Nu, pogodi! Its results led the authors to the conclusion that "elementary school children don't notice the moral background in cunning mouse Jerry's actions (the foreign animated cartoon Tom and Jerry), perceiving him as the same little character, as the Russian positive Hare... But the positive evaluation of Jerry's actions is obviously problematic: most of his actions cannot be approved. So, the animated cartoon Tom and Jerry is not advisable to watch without an adult's comments for preschoolers and elementary school children" (Matveeva et al., 2019: 119).

\section{Results}

The areas where the characters of the Soviet and the American animated cartoons live differ greatly. "Remember, as D. Zabolotskih puts it, any, the shabbiest American Mouse's hole. What can we see there? Right: a table and a bed. Meanwhile the Hare and the Wolf are not at all equipped in household. We don't know anything about where and how they live until the 14-th part of the series" (Zabolotskih, 1998).

The Wolf and the Hare are devoid of private lives. They don't have friends, relatives, hobbies. Still, they live in the society differently. The Woolf's social relations are full of conflicts. He is the only troublemaker in the animated world "he's constantly in search for a case to show off, to make a contact with the others" (Zabolotskih, 1998). He has no "followers". He is always let down by secondary characters: Rhino, Hippo, Cat Magician, Pig and others.

The Wolf is chasing the Hare not because he wants to eat him up, but due to the lack of something that the Hare possesses - nobility and moral purity. There is a great gap between them, which is successfully overcome by the Hare whereas the Wolf fails to overpass it. "Once an artist Rusakov was standing in a queue where he heard a talk between two men. One of them compared the Wolf with a typical worker and the Hare with a so called "intelligent" (a while-collar worker). "No matter how hard we try to catch him, he is always getting away" (Wait..., 2015).

The Wolf has neither private life nor his own rights, "that's why he never argues with the authorities", and he is "perfectly easy to be made work. Any the directing thick-skinned (represented in the cartoon by rhinos and hippos) can get him work and the Wolf obeys implicitly" (Zabolotskih, 1998).

The Hare's relations with the society are quite different. He isn't afraid of the Wolf, isn't angry with him and is always ready to forgive him, he is even sympathetic to him; he is always calm and jolly even walking alone in the night park. The Hare is the example, the ideal, spreading his inner harmony away.

The Hare lives in a cozy cultural environment. He is fully positive and is always dressed in the latest fashion of sports parades of the 30-s (a T-shirt and shorts). The formula of the character looks like this: "the poster social-realistic character minus the theme of study, labour and heroic act plus the author's irony - that's why he is very sporty, independent, naive” (Romanova, 2006). 
The actions of Tom and Jerry mostly take place at home. "The pet cat as opposed to Russian native characters, has to catch mice to have a bowl of milk, and in case of "professional inefficiency" he might be thrown away immediately (his horror) in that very Wednesday our characters' lives normally take place" (Zabolotskih, 1998).

The home environment, where Tom and Jerry live, is divided into their "private" territories. Tom is responsible to the Hostess for the order in the house and thereat behaves "as a host": plays the violin; picks fishing equipment; invites homeless cats to the house; takes food from the fridge and so on. Jerry has his simple "room-hole", comfortably furnished with a bed, a chair, a shelf, a desk with a lamp, and there is a street lamp near the entrance to his room.

The everyday area of the cartoon characters is strictly limited and its invasion can cause aggression of its "owner". However, often it is caused by the animal instinct. "In some series both the Cat and the Mouse behave obviously cruelly: burn, explode, but do it smartly and with specific American humour. The characters can also spend time "adultly" (for instance, Tom) spending time with a cute kitty and a cigar" (Ostapenko, 2019).

\section{Conclusion}

The anthropomorphic animal worlds of $\mathrm{Nu}$, pogodi! and Tom and Jerry represent two different cultures. In $\mathrm{Nu}$, pogodi! the utopian idyll of the Soviet folkloric characters is depicted, which is based on the deep-rooted Russian values such as absence of violence, self-sacrifice, fellowship, forgiveness. In Tom and Jerry the egoistic world of American characters is created, built upon the culture of self affirmation, individual success and prosperity.

The essence of Tom and Jerry's cruelty is rooted in their striving for material and social riches achievement and in the impossibility of finding any other ways of its satisfaction. Their inner world is intermediated by the outer world - the cultural models of thinking and behavior, aimed at private territory and personal boundaries building. Unfortunately, they (the boundaries) are very seldom overcome, generally in situations when one of the characters gets into trouble or is seriously injured.

The animation world of $\mathrm{Nu}$, pogodi! is absolutely beneficial to all its characters, even to the Wolf. The reason of his troubles is his own behavior. The Hare is always eager to help him, never refusing to "a friend" in fellowship. He never bears wrong, moreover, he doesn't hold grudges against him.

\section{References}

Alesicheva, 2021 - Alesicheva, T. (2021). Tom i Dzherri: Za chto nagrazhdali i osuzhdali mul'tfil'm [Tom and Jerry: For what the cartoon was awarded and condemned]. Kinoreporter. [Electronic resource]. URL: https://kinoreporter.ru/tom-i-dzherri-za-chto-nagrazhdali-i-osuzhdal i-multfilm/ [in Russian]

Aravind, 2011 - Aravind, A. (2011). Mammy Two Shoes: subversion and reaffirmation of racial stereotypes in Tom and Jerry. The IUP Journal of History and Culture. 3: 76-83. [Electronic resource]. URL: https://ssrn.com/abstract $=2064656$

Darling-Wolf, 2015 - Darling-Wolf, F. (2015). Imagining the Global: transnational media and popular culture beyond East and West. Michigan: University of Michigan Press. 192 p. DOI: http://dx.doi.org/10.3998/nmw.12748915.0001.001

Davydov, Moroz, 2019 - Davydov, I., Moroz, O. (2019). Volka zhalko. “Nu, pogodi!” s tochki zreniya sovremennoy etiki [Sorry for the wolf. "Wait for it!" from the point of view of modern ethics]. BBC News Russian Service. [Electronic resource]. URL: https://news.tut.by/culture/ 661640.html [in Russian]

Hassan, Daniyal, 2013 - Hassan, A., Daniyal, M. (2013). Cartoon Network and its impact on behavior of school going children: A case of Bahwalpur, Pakistan. International Journal of Management, Economics and Social Sciences (IJMESS). 2: 6-11. [Electronic resource]. URL: https://www.econstor.eu/bitstream/10419/71155/1/740140388.pdf

Elizarov, 2018 - Elizarov, M. (2018). Razbor "Nu pogodi” v seksual'nom aspekte [Analysis of "Just you wait" in the sexual aspect]. Pikabu. [Electronic resource]. URL: https://pikabu.ru/story/ razbor_nu_pogodi_v_seksualnom_aspekte_5326362 [in Russian]

Zabolotskikh, 1998 - Zabolotskikh, D. (1998). Skazka o sovershennom vremeni [The Tale of Perfect Time]. Iskusstvo kino - Cinema Art. 10. [Electronic resource]. URL: http://old.kinoart.ru/ archive/1998/10/n10-article15 [in Russian] 
Kropotkin, 2021 - Kropotkin, K. (2021). "Luchshiy moy podarochek - eto ty!" Gomoseksual'nyy golod v mul'tseriale "Nu, pogodi!" ["My best present is you!" Homosexual hunger in the animated series "Wait a minute!"]. Republic. [Electronic resource]. URL: https://republic.ru/posts/99236 [in Russian]

Matveeva et al., 2019 - Matveeva, L.V., Anikeeva, T.Ya., Mochalova, Yu.V., Makalatia, A.G. (2019). Vospriyatiye det'mi doshkol'nogo i mladshego shkol'nogo vozrasta obrazov geroyev otechestvennykh i zarubezhnykh mul'tfil'makh [Perception of images of heroes of domestic and foreign cartoons by children of preschool and primary school age]. Bulletin of Moscow University. Series 14. Psychology. 3: 105-123. DOI: 10.11621/vsp.2019.03.105 [in Russian]

Wait..., 2015 - “Nu, pogodi!". Nepridumannaya istoriya [“Wait for it!”. An invented story]. IVI. [Electronic resource]. URL: https://www.ivi.ru/titr/everything/nupogodiistoriya [in Russian]

Ostapenko, 2019 - Ostapenko, L. (2019). "Tom i Dzherri” VS "Nu, pogodi”. Kak sozdavalas' klassika amerikanskoy i sovetskoy mul'tiplikatsii ["Tom and Jerry" VS "Well, wait a minute." How the classics of American and Soviet animation were created]. Daily Baby. [Electronic resource]. URL: https://dailybaby.ru/magazine/articles/tom-i-dzherri-vs-nu-pogodi-kak-sozdavalas-klassika-amerika nskoi-i-sovetskoi-multiplikatsii [in Russian]

Romanova, 2006 - Romanova, O. (2006). "Nu, pogodi!", ili begotnya na fone "zastoya" ["Well, wait!", Or running around against the background of "stagnation"]. Polit.ru. [Electronic resource]. URL: https://polit.ru/article/2006/o9/22/nupogodi/ [in Russian] 